\title{
The European Union as a security actor: Cooperative multilateralism
}

\section{Sven Biscop \& Thomas Renard ${ }^{l}$}

If the term 'Cooperative Security' is rarely used in European Union (EU) parlance, it is at the heart of the EU's approach to security as expressed in its 2003 European Security Strategy (ESS), ${ }^{2}$ together with its comprehensive or holistic nature and its emphasis on conflict prevention.

First of all, and traditionally perhaps, Cooperative Security is pursued in what the EU calls its 'Neighbourhood': 'Our task is to promote a ring of wellgoverned countries to the East of the European Union and on the borders of the Mediterranean with whom we can enjoy close and cooperative relations', says the ESS. The EU pursues this via a strategy of positive conditionality: partnership and access to European markets are to stimulate security cooperation and political, social and economic reforms, thus spreading the EU's model and values. Cooperative Security and comprehensive or holistic security are thus two sides of the same coin.

More recent is the extension of Cooperative Security at the global level, under the guise of 'effective multilateralism': 'We need to pursue our objectives both through multilateral cooperation in international organizations and through partnerships with key actors', according to the ESS, which calls for 'Strategic Partnerships' with 'all those who share our goals and values and are prepared to act in their support'. This extension of the approach at the global level goes hand in hand with the EU's slow but steady development as a global actor, and is provoked by the current global environment. Marked by increasing multipolarity, i.e. the rise of 'emerging' or 're-emerging' global actors, the 'changing world order' creates a sense of urgency. These powers include Brazil, Russia, India and China, commonly known as the BRIC's, as well as other States with a global scope in one or more policy areas. For Cooperative Security and multilateralism to work and peaceful resolution of disputes to continue, these States too, many of which have a very different model and values from that of the EU, have to be integrated and socialized into the web of regimes, treaties and institutions. The world is not just increasingly multipolar, it is also characterized by increasing interdependence between the poles, which ought to facilitate cooperation. Although other global actors often have different worldviews and competing objectives, all are increasingly interlinked economically, and all are confronted with the same 
complex global challenges. Giovanni Grevi has dubbed this condition 'interpolarity': global interdependence is so great that 'its mismanagement can threaten not only the prosperity, but the political stability and ultimately, in extreme cases, the very survival of the actors that belong to the system'; therefore 'the ability to shape multilateral cooperation or lead collective action in addressing international challenges becomes a central feature of power'. ${ }^{3}$

The 'interpolar' world thus presents both a challenge and an opportunity for Cooperative Security. In December 2008, after a year-long debate about the ESS, the EU confirmed its approach in 'a report on the Implementation of the European Security Strategy - Providing Security in a Changing World' ${ }^{4}$ The report perceives a crucial window of opportunity: 'At a global level, Europe must lead a renewal of the multilateral order. (...) We have a unique moment to renew multilateralism, working with the United States and with our partners around the world'. But are the EU's traditional, conditionality-based policies sufficient to achieve this?

\section{Cooperation rather than conditionality}

Arguably, what is most distinctive about the EU is what can be called the European social model: the combination of democracy, the market economy, and strong state intervention, at Member State and EU level, to ensure regulation of the economy and social security. This model, including the values on which it is based, can be conceptualized as an integral whole of public goods, to which every citizen is entitled, and which it is the responsibility of government to provide to every citizen: security or freedom from fear; economic prosperity or freedom from want; political freedom, i.e. democracy, respect for human rights, and the rule of law; and social well-being, i.e. health, education, and a sustainable environment. ${ }^{5}$ An assessment of the conditions that have to be fulfilled for this model to prosper, allows identification of the EU's vital interests, i.e. those that determine the very survival of its model: the absence of a vital military threat to the territory of the Union; open lines of communication and trade (in physical as well as in cyber space); a secure energy supply; a clean and stable environment; manageable migration flows; the maintenance of international law and universally agreed rights; and autonomy of EU decision-making.

In an 'interpolar' world, without direct enemies to the EU, and in which cooperation to tackle common challenges is vital, the best way of defending EU interests in order to defend its model and values, is precisely to spread those values. Increasing the access of citizens worldwide to these same core public goods directly addresses the root causes of threats and challenges. In other words,

3 Giovanni Grevi, The Interpolar World: A New Scenario. Occasional Paper 79. Paris, EUISS, 2009, p. 24, see http://www.iss.europa.eu/uploads/media/op79.pdf.

See http://www.consilium.europa.eu/ueDocs/cms_Data/docs/pressData/en/reports/10463 0 .pdf.

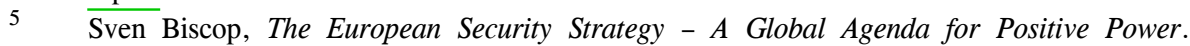
Aldershot, Ashgate Publishing, 2005. 
if the fundamental objective of the EU is the preservation and strengthening of the European social model and the values on which it is based, the best way of achieving that is to promote it in the rest of the world, which moreover constitutes a positive agenda in its own right. ${ }^{6}$

However, vis-à-vis other global actors, the classic EU strategy of 'positive conditionality' has great limitations. Interdependence is too great and the scale of things is too vast for the EU to have any serious leverage. On the contrary, pontificating without acting only serves to undermine EU soft power. Global powers cannot be enticed by the offer of the proverbial carrot - they can only be convinced of the value of the EU model through practical cooperation on concrete issues, on the basis of shared interests and common challenges.

\section{A new instrument: Strategic Partnerships}

The EU has therefore created a new instrument to engage with other global actors: Strategic Partnerships. The actual strategy behind these is far from clear, however.

A first and major problem is the lack of understanding of the concept of Strategic Partnership. It has never been defined and is consequently seen and interpreted differently by many actors within the EU, without mentioning those outside the EU. Similarly, the objectives of the Strategic Partnerships are illdefined. Apart from installing various annual meetings and summits, it is not clear what the creation of a Strategic Partnership entails: which common objectives and especially joint actions are to be pursued in which policy areas? Who takes the lead in these partnerships on the EU side? Often it appears as if the existence of a partnership is more important than its content and its potential for the EU and for the bilateral relationship. Of course, Strategic Partnerships are a well-understood means to insert a new dynamic into a relationship that is deemed to be important. They also aim at providing a 'comprehensive, coherent, and coordinated longterm framework" to the relationship. But the role of these partnerships in the context of 'effective multilateralism' remains unclear.

Another major problem relates to the countries that qualify for a Strategic Partnership. There are few established criteria, except that partnerships can be signed with 'third countries, and international, regional or global organisations which share the principles (of democracy, the rule of law, the universality and indivisibility of human rights and fundamental freedoms, respect for human dignity, the principles of equality and solidarity, and respect for the principles of the United Nations Charter and international law)' (Lisbon Treaty, Article 22) and that 'the strategic partner status is specifically intended to derive from the capacity of a country to exert a significant influence on global issues' ${ }^{8}$ At this point, not

6 Sven Biscop (ed.), The Value of Power, the Power of Values - A Call for an EU Grand Strategy. Egmont Paper No. 33. Brussels, Egmont, 2009, see http://www.egmontinstitute.be/paperegm/ep33.pdf.

$7 \quad$ Towards an EU-South Africa Strategic Partnership, COM(2006) 347, Brussels, 28 June 2006.

$8 \quad$ Towards an EU-Mexico Strategic Partnership, $\operatorname{COM(2008)~447,~Brussels,~} 15$ July 2008. 
counting relations with the US, Canada and NATO, the EU has or is negotiating seven Strategic Partnerships with other States (Brazil, China, India, Japan, Mexico, Russia, and South Africa), and one with an international organization (the African Union). It seems quite obvious that not each of these is equally strategic. Most of these countries undeniably exercise regional leadership or are a significant player for one specific global issue. This makes them strategic as regards one region, or one issue. But is this a sufficient condition to make them a strategic partner? Can Mexico and South Africa really be put on an identical level with China, Russia and the United States?

The danger is to overstretch the concept, on the one hand, leading to an amalgam between important relationships and strategic relationships. Such overstretch creates confusion within the EU, but also in the eyes of its partners and in the way they interpret Europe's ambitions. On the other hand, there is an equal - and tightly related - risk of diluting the symbolic but real importance of the concept with each new partnership. 'Strategic Partnership' has become a very fashionable term, emptied of its true substance.

\section{Towards a strategic use}

A truly strategic use of the Strategic Partnerships, i.e. in function of EU foreign policy, must start from a thorough assessment of EU interests in the various regions of the globe and a clearer definition of its objectives towards them. At the same time, a prioritization of actions to be taken to tackle the global challenges, in function of the Union's vital interests, is in order. On many of these issues climate, migration, energy - the EU already has elaborate policies - these must be integrated into its broader foreign policy framework. Finally, the EU must sharpen its view on how best to organize the multilateral architecture. To be effective and legitimate, the multilateral architecture must evidently be adapted to take into account the growing importance of the 'emerging' global actors. Can the $\mathrm{EU}$, which clearly is over-represented, contribute to such reforms while making its own representation more effective, e.g. by compensating for the loss of European seats by speaking much more with one voice? Which are the EU's preferred multilateral forums? Which organizations are best suited to deal with which issues, which reforms must be undertaken to strengthen their effectiveness and legitimacy, and how can the EU act united within them? How does the EU assess the growing role of the G20 e.g., how ought it to be represented there, and what should be the position of the G20 vis-à-vis the UN? The EU cannot afford to dither, for things are moving fast, as the rise of the G20 demonstrates. Without proactive EU involvement, Europe will be running behind the facts.

Taken together, these regional, global and institutional interests and objectives could inform a really strategic use of the Strategic Partnerships. Rather than objectives in their own right, the Strategic Partnerships are instruments to further 'effective multilateralism'. The EU could identify shared interests with each of its strategic partners, in order to establish in a number of priority policy areas effective practical cooperation with those strategic partners that share EU 
interests in that specific domain, with the ultimate aim of institutionalizing those forms of cooperation and linking them up with the permanent multilateral institutions. Such a pragmatic approach of coalition-building and practical cooperation, on very specific issues to start with, can expand into broader areas, including with regard to values. If e.g. it is unlikely that we will see China at the forefront of democracy promotion, it has an economic interest in promoting the rule of law, if only to ensure that the mining concessions it acquires are not simultaneously offered to someone else. Such a process could allow the EU to gradually and consensually increase the minimal standards to which everyone should adhere, thus slowly but surely strengthening the recognition of the universality of our values, while steadily increasing the integration of other global powers into a tight web of cooperative relations.

Rather than asking with which State or organization a Strategic Partnership should be concluded, the EU should look beyond those already in existence and involve actors in constructive cooperation in function of their power in the specific area concerned. In practice, two types of partners may eventually emerge: those with which the EU establishes cooperation in a comprehensive range of areas probably at least Russia, China and India, if they would be inclined to such cooperation that is, and of course the US; and those with whom cooperation focuses on a more limited range of issues or regions.

For the Strategic Partnerships to work, the EU must speak with one voice other global actors are only too adept at playing one Member State against the other. 'Self-divide and be ruled over' is not a strategy bound to serve European interests. At the very least, Member States should subscribe to a rule of transparency and automatically inform the EU, at an early stage, of all important bilateral arrangements with strategic partners, so as to allow for debate in the $\mathrm{EU}$ institutions and de-conflicting of potentially competing interests. Ideally, on key issues, Strategic Partnerships could establish the EU as the unique interlocutor on a series of key issues, hence limiting the margin of manoeuvre of individual Member States.

\section{Conclusion}

In a globalized and multipolar work, Cooperative Security or 'effective multilateralism' is as important as ever. The condition of 'interpolarity' does not guarantee the absence of tension or strife between the powers, but it constitutes a great opportunity. In the past international stability under conditions of multipolarity has been possible for long periods, when shared objectives linked the great powers together in a social contract which all subscribed to, not out of altruism, but because it allowed them to maintain great power status and to secure their vital interests. ${ }^{9}$ No environment could be more amenable to the creation of such a social contract than interpolarity. In that context, the EU's Strategic 
Partnerships are a very promising instrument. Without strategy, the Strategic Partnerships will quickly become irrelevant. With a strategy, they can potentially become very effective instruments of a united European foreign policy. 